\title{
Performance of wheat cultivars at varying fertility levels under system of wheat intensification and conventional method of wheat production system
}

\author{
Kaushik Chatterjee, C.S. Singh, A.K. Singh, Ashok Kr. Singh and S.K. Singh* \\ Department of Agronomy, Birsa Agricultural University, Kanke, Ranchi-834006 (Jharkhand), INDIA \\ *Corresponding author E-mail: sksinghbau@gmail.com
}

Received: December 21, 2015; Revised received: April 27, 2016; Accepted: July 31, 2016

\begin{abstract}
A field experiment was conducted during rabi season of 2009-10 at Ranchi, Jharkhand to evaluate the performance of wheat cultivars at varying fertility levels under system of wheat intensification and conventional method of cultivation. The morpho-physiological analysis of growth and yield in wheat revealed that system of wheat intensification manifested higher total tillers $\mathrm{m}^{-2}$, leaf area index, dry matter accumulation, crop growth rate, number of spikes $\mathrm{m}^{-2}$, grains per spike and 1000-grain weight resulting in higher grain and straw yield over conventional method of cultivation. The net return and benefit: cost ratio as well as the nutrient uptake of nitrogen, phosphorus and potash was also recorded significantly higher under system of wheat intensification. Higher fertility level of 120 $\mathrm{kg} \mathrm{N} \mathrm{ha}^{-1}, 60 \mathrm{~kg} \mathrm{P}_{2} \mathrm{O}_{5} \mathrm{ha}^{-1}$ and $40 \mathrm{~kg} \mathrm{~K}_{2} \mathrm{O}$ ha $^{-1}$ also significantly improved the plant height, total tillers $\mathrm{m}^{-2}$, leaf area index, dry matter accumulation, crop growth rate, number of spikes $\mathrm{m}^{-2}$, grains per spike, 1000-grain weight, grain yield, straw yield, net return, benefit: cost ratio and nutrient uptake of nitrogen, phosphorus and potash. Among the wheat cultivars, K 9107 manifested significant improvement in growth attributes at all the growth stages resulting in significantly higher yield attributes, grain yield, straw yield, net return, benefit: cost ratio and nutrient uptake of nitrogen, phosphorus and potash than Birsa Gehu 3, HUW 468 and K 0307 . Thus it can be concluded that the wheat variety $\mathrm{K} 9107$ fertilized with $120 \mathrm{~kg} \mathrm{~N}^{-1}, 60 \mathrm{~kg} \mathrm{P}_{2} \mathrm{O}_{5} \mathrm{ha}^{-1}$ and $40 \mathrm{~kg} \mathrm{~K}_{2} \mathrm{O}$ ha ${ }^{-1}$ under System of Wheat Intensification may able to boost up the wheat productivity under irrigated ecosystem of Chhotanagpur plateau region, India
\end{abstract}

Keywords: Crop growth rate, Leaf area index, Net assimilation rate, Relative growth rate, System of wheat intensification

\section{INTRODUCTION}

Agricultural production being an interactive effect of soil-water-fertilizer-ultimate continuum, a wise scientific management of this complies system is crucial for enhancing crop productivity on a sustained manner without giving any detrimental effect on environmental ecology. But, today the major part of the cereal growing areas is now threatened by issues like resource degradation, declining productivity, escalating input cost and diminishing return. However, our countries need further higher production to feed the ever increasing population at a rate of 1.8 per cent annually. This can be achieved only through changes in management practices to exploit the soil-water-fertilizer-climate continuum efficiency. System of Wheat Intensification (SWI) is a set of agronomic practices which has the potential for improvement of yield and factor productivity. It is based on the insights that wheat has the potential to produce more tillers and grains than now observed and wider spacing and optimal growth conditions can fulfill this potential. However, the potentiality of system of wheat intensification can only be judged under adequate and balanced fertilization (Chatterjee et. al. 2012). In SWI, wider spacing is recommended for vigorous root growth and profuse tiller- ing, however, it is variety dependent and location specific. So, the efficiency of production system coupled with suitable soil fertility can be further improved with the choice of right genotype of wheat well adapted to this region. Therefore, it is high time to strengthen the research programme on such management technology like system of wheat intensification not only to maximize production but also to make it sustainable. Hence, present experiment was undertaken to evaluate wheat cultivars at varying fertility level for their suitability under system of wheat intensification.

\section{MATERIALS AND METHODS}

A field experiment was undertaken at Agronomy Research farm, Birsa Agricultural University at Kanke, Ranchi under irrigated condition during rabi season of 2009-10. The soil (Alfisol) of the experimental site was poor in fertility, acidic in reaction ( $\mathrm{pH}$ 5.6), sandyclay loam in texture, low in organic carbon $\left(3.7 \mathrm{~g} \mathrm{~kg}^{-}\right.$ $\left.{ }^{1}\right)$, available nitrogen $\left(253.42 \mathrm{~kg} \mathrm{ha}^{-1}\right)$, medium in available phosphorus (12.18 $\mathrm{kg} \mathrm{ha}^{-1}$ ) and available potassium (155.0 $\mathrm{kg} \mathrm{ha}^{-1}$ ) The experiment was laid out in randomized block design with twenty treatments replicated thrice. The treatment combinations consisted of method of cultivation, i.e., System of Wheat intensification $\left(\mathrm{M}_{1}\right)$ and conventional method $\left(\mathrm{M}_{2}\right)$; two fer- 
tility levels, i.e., $80 \mathrm{~kg} \mathrm{~N} \mathrm{ha}^{-1}, 40 \mathrm{~kg} \mathrm{P}_{2} \mathrm{O}_{5} \mathrm{ha}^{-1}$ and 20 $\mathrm{kg} \mathrm{K}_{2} \mathrm{O} \mathrm{ha}^{-1}\left(\mathrm{~F}_{1}\right)$ and $120 \mathrm{~kg} \mathrm{~N} \mathrm{ha}^{-1}, 60 \mathrm{~kg} \mathrm{P}_{2} \mathrm{O}_{5} \mathrm{ha}^{-1}$ and $40 \mathrm{~kg} \mathrm{~K}_{2} \mathrm{O} \mathrm{ha}^{-1}\left(\mathrm{~F}_{2}\right)$ and 5 wheat cultivars i.e., $\mathrm{K} 9107$ $\left(\mathrm{V}_{1}\right)$, Birsa Gehu3 $\left(\mathrm{V}_{2}\right)$, HUW $468\left(\mathrm{~V}_{3}\right)$, HUW 234 $\left(\mathrm{V}_{4}\right)$ and $\mathrm{K} 0307\left(\mathrm{~V}_{5}\right)$. Well rotten FYM @ 10 tonnes $\mathrm{ha}^{-1}$ was applied at the time of last ploughing. System of wheat intensification involves seed treatment with $60^{\circ} \mathrm{C}$ hot water (20 litre per $10 \mathrm{~kg}$ seed) for $1 / 2$ an hour. The infertile and damaged seeds floating over the water should be removed. Then seeds were soaked in a mixture of 4 litre cow urine, $5 \mathrm{~kg}$ vermicompost and 4 kg jaggery for 8 hours and left overnight in moist jute bag to break the dormancy of seeds. Single seed is sown at row to row and plant to plant spacing of $20 \times$ $20 \mathrm{~cm}$. The wheat crop under system of rice intensification was irrigated at 15, 25, 35, 65, 85 and 105 days after sowing. The nutrient requirement of the crop was met through diammonium phosphate $(18 \% \mathrm{~N}$ and $15 \%$ $\left.\mathrm{P}_{2} \mathrm{O}_{5}\right)$, muriate of potash $\left(60 \% \mathrm{~K}_{2} \mathrm{O}\right)$ and urea $(46 \% \mathrm{~N})$. Full dose of phosphorus, 50 per cent of potash and 1/3 of nitrogen were applied as basal application and rest $2 / 3$ of nitrogen is applied in two splits 2 days after $1^{\text {st }}$ and $3^{\text {rd }}$ irrigation as per treatment. The remaining 50 per cent of the potash is applied at the time of spike emergence. Weeding was done by using mechanical weeder at 3-4 days after $1^{\text {st }}, 2^{\text {nd }}$ and $3^{\text {rd }}$ irrigation after top dressing of fertilizer. In conventional method seeds of particular cultivar were sown in regular rows of 20 $\mathrm{cm}$ with a seed rate of $125 \mathrm{~kg} \mathrm{ha}^{-1}$. A basal dose of full $\mathrm{P}_{2} \mathrm{O}_{5}$ in the form of diammonium phosphate (DAP), $\mathrm{K}_{2} \mathrm{O}$ through muriate of potash and $1 / 3$ of the nitrogen through urea was applied as basal application as per treatment. The remaining $2 / 3$ of nitrogen was top dressed in two equal splits at 20 and 40 days after sowing. Altogether six irrigation were applied at an interval of 20 days throughout the crop growth period. Two hand weeding was done at 20 and 40 days after sowing. Need-based plant protection measures were given. Plants sampling was done at 20,40,60, 80, 100 days after sowing and at harvest to record the growth parameters such as plant height, total tiller $\mathrm{m}^{-2}$, leaf area index and dry matter accumulation per $\mathrm{m}^{2}$ while the yield attributes, grain yield and straw yield were recorded at harvest.

The plant samples collected at harvest were dried at $70^{\circ} \mathrm{C}$, powdered in Willey mill and digested to analyze the various nutrient compositions. The nitrogen, phosphorus and potassium content in plant parts were estimated by Kessler's reagent method (Nicholas and Nason, 1957), $\mathrm{HNO}_{3}: \mathrm{HClO}_{4}(9: 4)$ digestion, colour development by Vandomolybdate solution followed by spectrophotometer determination (Jackson, 1973) and flame photometric determination after digestion in $\mathrm{HNO}_{3}: \mathrm{HClO}_{4}$ (9:4) (Jackson, 1973) respectively. The nutrient uptake was estimated by multiplying the nutrient concentration with the grain and straw yield. The data were subjected to statistical analysis as prescribed by Gomez and Gomez (1984) and significant effects were presented and discussed in this paper. The economics was computed on the basis of prevailing market rates of produce and agro-inputs. Net return was the difference between the gross returns and total cost of cultivation. The benefit: cost ratio was calculated by dividing the net returns by the cost of cultivation.

\section{RESULTS AND DISCUSSION}

Plant height: There was a gradual increase in plant height till maturity. This was mainly due to increase in the length of leaves and spike till harvest (Table 1). System of wheat intensification recorded significantly higher plant height than conventional method of cultivation at 20 days after sowing. This might be due to early germination of seeds in system of wheat intensification than conventional method. At later stages, conventional method of cultivation had higher plant height than SWI method as dense plant population in conventional method favour the vertical growth of plant in search of light while, greater spacing provided in system of wheat intensification leading to lesser competition between the plants thus favouring horizontal spread to utilize the available space resulting in shorter plant than conventional method. Increasing fertility level increased the plant height and maximum plant height was observed with $120 \mathrm{~kg} \mathrm{~N}^{-1}, 60 \mathrm{~kg}$ $\mathrm{P}_{2} \mathrm{O}_{5} \mathrm{ha}^{-1}$ and $40 \mathrm{~kg} \mathrm{~K}_{2} \mathrm{O}$ ha $^{-1}$ due to improved N, P, K supplying capacity of soil at higher fertility level. Plant height is the genetic character of the cultivar which is much dependent on management practices as such $\mathrm{K}$ 9107 was higher in plant height than Birsa Gehu 3, HUW 234, HUW 468 and K 0307 (Bhardwaj et al. 2010).

Total tillers per $\mathbf{m}^{2}$ : Total tillers $\mathrm{m}^{-2}$ was higher at 80 days after sowing and then declined afterwards till harvest (Table 1). The reduction in tillers after 80 DAT was due to intra species competition for higher space and nutrients which are responsible for degeneration of late formed tillers. System of wheat intensification had higher tiller numbers as under wider spacing each individual plant could have effectively utilized the more available resources such as space, foraging area for root system, better root spread, more light interception etc., which resulted in enhanced tiller production as compared to conventional system of cultivation (Thakur et. al. 2010). Number of tillers $\mathrm{m}^{-2}$ were increased significantly at higher fertility level i.e., $120 \mathrm{~kg}$ $\mathrm{N} \mathrm{ha}^{-1}, 60 \mathrm{~kg} \mathrm{P}_{2} \mathrm{O}_{5} \mathrm{ha}^{-1}$ and $40 \mathrm{~kg} \mathrm{~K}_{2} \mathrm{O} \mathrm{ha}^{-1}$ at all the growth stages. Cultivars influenced the tiller growth throughout the growth period. At maturity, K 9107 produced the highest tiller number and was followed by HUW-234, K 0307; HUW-468 and Birsa Gehu-3 as the cultivar differ in their ability to produce tillers due to differences in genetic constitution (Mehla and Gupta 1998).

Leaf area index: Leaf area index increased successively as the growth progressed upto 80 days after sowing and thereafter it declined till harvest due to 
Kaushik Chatterjee et al. / J. Appl. \& Nat. Sci. 8 (3): 1427 - 1433 (2016)

Table 1. Effect of cultivation method and fertility levels on plant height, total tillers, leaf area index and dry matter accumulation of wheat cultivars.

\begin{tabular}{|c|c|c|c|c|c|c|c|c|c|c|c|c|c|}
\hline $\begin{array}{l}\text { Treat- } \\
\text { ments }\end{array}$ & 20 DAS & 40 DAS & 60 DAS & 80 DAS & 100 DAS & $\begin{array}{c}\text { At Ma- } \\
\text { turity }\end{array}$ & $\begin{array}{l}\text { Treat- } \\
\text { ments }\end{array}$ & 20 DAS & 40 DAS & 60 DAS & 80 DAS & 100 DAS & $\begin{array}{c}\text { At Ma- } \\
\text { turity }\end{array}$ \\
\hline \multicolumn{7}{|c|}{ Plant height $(\mathrm{cm})$} & \multicolumn{7}{|c|}{ Tillers / $\mathbf{m}^{2}$} \\
\hline \multicolumn{7}{|c|}{ Method of cultivation } & \multicolumn{7}{|c|}{ Method of cultivation } \\
\hline SWI & 8.72 & 24.61 & 51.06 & 82.52 & 96.29 & 96.14 & SWI & 49.93 & 117.93 & 451.39 & 520.41 & 485.92 & 454.10 \\
\hline $\begin{array}{l}\text { Conven- } \\
\text { tional }\end{array}$ & 8.31 & 26.19 & 54.78 & 85.88 & 99.04 & 98.83 & $\begin{array}{l}\text { Conven- } \\
\text { tional }\end{array}$ & 280.39 & 350.39 & 400.27 & 476.51 & 428.75 & 410.48 \\
\hline $\begin{array}{l}\mathrm{CD} \\
(\mathrm{P}=0.05)\end{array}$ & 0.35 & 1.23 & 2.83 & NS & NS & NS & $\begin{array}{l}\mathrm{CD} \\
(\mathrm{P}=0.05)\end{array}$ & 11.29 & 11.29 & 23.91 & 32.04 & 23.74 & 23.33 \\
\hline \multicolumn{7}{|c|}{ Fertility levels ( $\mathrm{kg} \mathrm{N}-\mathrm{P}_{2} \mathrm{O}_{5}-\mathrm{K}_{2} \mathrm{O} / \mathrm{ha}$ ) } & \multicolumn{7}{|c|}{ Fertility levels $\left(\mathrm{kg} \mathrm{N}-\mathrm{P}_{2} \mathrm{O}_{5}-\mathrm{K}_{2} \mathrm{O} / \mathrm{ha}\right)$} \\
\hline $80-40-20$ & 8.26 & 24.21 & 50.01 & 80.50 & 94.69 & 94.12 & $80-40-20$ & 160.52 & 218.02 & 369.62 & 458.75 & 432.67 & 407.58 \\
\hline $120-60-40$ & 8.76 & 26.59 & 55.83 & 87.90 & 100.63 & 100.85 & $120-60-40$ & 169.79 & 250.29 & 482.04 & 538.17 & 482.00 & 457.01 \\
\hline $\begin{array}{l}\mathrm{CD} \\
(\mathrm{P}=0.05)\end{array}$ & 0.35 & 1.23 & 2.83 & 4.43 & 4.77 & 4.90 & $\begin{array}{l}\mathrm{CD} \\
(\mathrm{P}=0.05)\end{array}$ & NS & 11.29 & 23.91 & 32.04 & 23.74 & 23.33 \\
\hline \multicolumn{7}{|l|}{ Cultivars } & \multicolumn{7}{|l|}{ Cultivars } \\
\hline K 9107 & 9.37 & 27.77 & 59.25 & 92.94 & 108.59 & 108.48 & K 9107 & 170.62 & 251.12 & 480.10 & 538.66 & 497.29 & 473.32 \\
\hline $\begin{array}{l}\text { Birsa } \\
\text { Gehu } 3\end{array}$ & 7.59 & 21.93 & 45.79 & 77.41 & 87.28 & 87.01 & $\begin{array}{l}\text { Birsa } \\
\text { Gehu } 3\end{array}$ & 157.53 & 205.53 & 346.35 & 467.84 & 420.63 & 408.23 \\
\hline HUW 468 & 7.63 & 25.22 & 48.87 & 79.41 & 93.37 & 93.31 & HUW 468 & 162.67 & 223.17 & 393.20 & 481.80 & 445.00 & 419.38 \\
\hline HUW 234 & 9.28 & 26.77 & 58.17 & 86.73 & 100.53 & 100.14 & HUW 234 & 169.22 & 249.72 & 458.98 & 514.30 & 465.00 & 431.61 \\
\hline К 0307 & 8.70 & 25.32 & 52.52 & 84.51 & 98.54 & 98.49 & К 0307 & 165.74 & 241.24 & 450.52 & 489.70 & 458.75 & 428.93 \\
\hline $\begin{array}{l}\mathrm{CD} \\
(\mathrm{P}=0.05)\end{array}$ & 0.56 & 1.94 & 4.47 & 7.01 & 7.55 & 7.75 & $\begin{array}{l}\mathrm{CD} \\
(\mathrm{P}=0.05)\end{array}$ & NS & 17.85 & 37.81 & 50.66 & 37.54 & 36.88 \\
\hline \multicolumn{7}{|c|}{ Leaf area index } & \multicolumn{7}{|c|}{ Dry matter accumulation $\left(\mathrm{g} / \mathrm{m}^{2}\right)$} \\
\hline \multicolumn{7}{|c|}{ Method of cultivation } & \multicolumn{7}{|c|}{ Method of cultivation } \\
\hline SWI & 0.33 & 1.24 & 2.52 & 3.71 & 2.83 & 1.42 & SWI & 7.43 & 57.86 & 197.87 & 568.43 & 920.61 & 1123.06 \\
\hline $\begin{array}{l}\text { Conven- } \\
\text { tional }\end{array}$ & 0.44 & 1.15 & 2.29 & 3.53 & 2.69 & 1.35 & $\begin{array}{l}\text { Conven- } \\
\text { tional }\end{array}$ & 14.52 & 56.03 & 183.63 & 515.10 & 835.08 & 1004.31 \\
\hline $\begin{array}{l}\mathrm{CD} \\
(\mathrm{P}=0.05)\end{array}$ & 0.02 & 0.06 & 0.15 & 0.18 & NS & NS & $\begin{array}{l}\mathrm{CD} \\
(\mathrm{P}=0.05)\end{array}$ & 0.71 & NS & 7.77 & 23.45 & 39.07 & 45.14 \\
\hline \multicolumn{7}{|c|}{ Fertility levels ( $\mathrm{kg} \mathrm{N}-\mathrm{P}_{2} \mathrm{O}_{5}-\mathrm{K}_{2} \mathrm{O} / \mathrm{ha}$ ) } & \multicolumn{7}{|c|}{ Fertility levels (kg N-P $\left.\mathrm{O}_{5}-\mathrm{K}_{2} \mathrm{O} / \mathrm{ha}\right)$} \\
\hline $80-40-20$ & 0.36 & 1.10 & 2.18 & 3.38 & 2.55 & 1.27 & $80-40-20$ & 10.67 & 52.05 & 172.12 & 485.37 & 798.29 & 954.18 \\
\hline $120-60-40$ & 0.41 & 1.28 & 2.63 & 3.85 & 2.97 & 1.50 & $120-60-40$ & 11.67 & 61.84 & 209.38 & 598.16 & 957.40 & 1173.19 \\
\hline $\begin{array}{l}\mathrm{CD} \\
(\mathrm{P}=0.05)\end{array}$ & 0.02 & 0.06 & 0.15 & 0.18 & 0.18 & 0.08 & $\begin{array}{l}\mathrm{CD} \\
(\mathrm{P}=0.05)\end{array}$ & 0.71 & 2.50 & 7.77 & 23.45 & 39.07 & 45.14 \\
\hline \multicolumn{7}{|l|}{ Cultivars } & \multicolumn{7}{|l|}{ Cultivars } \\
\hline K 9107 & 0.44 & 1.26 & 2.58 & 3.78 & 2.90 & 1.49 & K 9107 & 11.92 & 60.94 & 206.91 & 602.75 & 960.94 & 1172.59 \\
\hline $\begin{array}{l}\text { Birsa } \\
\text { Gehu } 3\end{array}$ & 0.32 & 1.12 & 2.22 & 3.37 & 2.56 & 1.25 & $\begin{array}{l}\text { Birsa } \\
\text { Gehu } 3\end{array}$ & 10.15 & 51.79 & 171.82 & 479.91 & 786.87 & 949.37 \\
\hline HUW 468 & 0.37 & 1.16 & 2.28 & 3.60 & 2.60 & 1.32 & HUW 468 & 10.99 & 54.42 & 181.44 & 505.95 & 840.53 & 996.43 \\
\hline HUW 234 & 0.39 & 1.22 & 2.47 & 3.70 & 2.88 & 1.47 & HUW 234 & 11.62 & 60.07 & 202.63 & 570.83 & 916.69 & 1117.36 \\
\hline К 0307 & 0.39 & 1.20 & 2.47 & 3.65 & 2.86 & 1.40 & К 0307 & 11.18 & 57.51 & 190.94 & 549.38 & 884.20 & 1082.66 \\
\hline $\begin{array}{l}\mathrm{CD} \\
(\mathrm{P}=0.05)\end{array}$ & 0.03 & 0.10 & 0.24 & 0.29 & 0.28 & 0.12 & $\begin{array}{l}\mathrm{CD} \\
(\mathrm{P}=0.05)\end{array}$ & 1.12 & 3.95 & 12.29 & 37.07 & 61.77 & 71.38 \\
\hline
\end{tabular}


Kaushik Chatterjee et al. / J. Appl. \& Nat. Sci. 8 (3): 1427 - 1433 (2016)

Table 2. Effect of cultivation method and fertility level on crop growth rate, relative growth rate and net assimilation rate of wheat cultivars.

\begin{tabular}{|c|c|c|c|c|c|}
\hline Treatments & 20-40 DAS & 40-60 DAS & 60-80 DAS & 80-100 DAS & 100DAS- Maturity \\
\hline \multicolumn{6}{|c|}{ Crop growth rate ( $\mathrm{g} \mathrm{m}^{-2}$ day) } \\
\hline \multicolumn{6}{|c|}{ Method of cultivation } \\
\hline SWI & 2.51 & 7.00 & 18.53 & 17.61 & 10.12 \\
\hline Conventional & 2.07 & 6.38 & 16.57 & 16.00 & 8.46 \\
\hline $\mathrm{CD}(\mathrm{P}=0.05)$ & 0.14 & 0.42 & 1.26 & 1.45 & 0.91 \\
\hline \multicolumn{6}{|c|}{ Fertility levels ( $\mathrm{kg} \mathrm{N}-\mathrm{P}_{2} \mathrm{O}_{5}-\mathrm{K}_{2} \mathrm{O} / \mathrm{ha}$ ) } \\
\hline $80-40-20$ & 2.07 & 6.00 & 15.66 & 15.65 & 7.79 \\
\hline $120-60-40$ & 2.51 & 7.38 & 19.44 & 17.96 & 10.79 \\
\hline $\mathrm{CD}(\mathrm{P}=0.05)$ & 0.14 & 0.42 & 1.26 & 1.45 & 0.91 \\
\hline \multicolumn{6}{|l|}{ Cultivars } \\
\hline K 9107 & 2.45 & 7.30 & 19.79 & 17.91 & 10.58 \\
\hline Birsa Gahu-3 & 2.08 & 6.00 & 15.40 & 15.35 & 8.13 \\
\hline HUW 468 & 2.17 & 6.35 & 16.23 & 16.73 & 7.79 \\
\hline HUW 234 & 2.42 & 7.13 & 18.41 & 17.29 & 10.03 \\
\hline К 0307 & 2.32 & 6.67 & 17.92 & 16.74 & 9.92 \\
\hline $\mathrm{CD}(\mathrm{P}=0.05)$ & 0.21 & 0.66 & 1.99 & 2.30 & 1.44 \\
\hline \multicolumn{6}{|c|}{ Relative growth rate $\left(\mathrm{g}^{-1} \mathrm{~g}^{-1}\right.$ day $)$} \\
\hline \multicolumn{6}{|c|}{ Method of cultivation } \\
\hline SWI & 0.0441 & 0.0270 & 0.0228 & 0.0106 & 0.0042 \\
\hline Conventional & 0.0297 & 0.0258 & 0.0224 & 0.0103 & 0.0041 \\
\hline $\mathrm{CD}(\mathrm{P}=0.05)$ & 0.0019 & NS & NS & NS & NS \\
\hline \multicolumn{6}{|c|}{ Fertility levels $\left(\mathrm{kg} \mathrm{N}-\mathrm{P}_{2} \mathrm{O}_{5}-\mathrm{K}_{2} \mathrm{O} / \mathrm{ha}\right)$} \\
\hline $80-40-20$ & 0.0368 & 0.0263 & 0.0225 & 0.0104 & 0.0041 \\
\hline $120-60-40$ & 0.0370 & 0.0265 & 0.0227 & 0.0105 & 0.0042 \\
\hline $\mathrm{CD}(\mathrm{P}=0.05)$ & NS & NS & NS & NS & NS \\
\hline \multicolumn{6}{|l|}{ Cultivars } \\
\hline K 9107 & 0.0382 & 0.0266 & 0.0228 & 0.0106 & 0.0043 \\
\hline Birsa Gahu-3 & 0.0358 & 0.0261 & 0.0223 & 0.0103 & 0.0040 \\
\hline HUW 468 & 0.0358 & 0.0263 & 0.0225 & 0.0103 & 0.0040 \\
\hline HUW 234 & 0.0382 & 0.0264 & 0.0227 & 0.0105 & 0.0043 \\
\hline К 0307 & 0.0364 & 0.0264 & 0.0225 & 0.0105 & 0.0041 \\
\hline $\mathrm{CD}(\mathrm{P}=0.05)$ & 0.0030 & 0.0022 & 0.0021 & 0.0013 & 0.0007 \\
\hline \multicolumn{6}{|c|}{ Net assimilation rate $\left(\mathrm{g} \mathrm{m}^{-2}\right.$ day $)$} \\
\hline \multicolumn{6}{|c|}{ Method of cultivation } \\
\hline SWI & 3.76 & 4.02 & 6.14 & 5.63 & 4.95 \\
\hline Conventional & 2.87 & 4.01 & 6.13 & 5.68 & 4.41 \\
\hline $\mathrm{CD}(\mathrm{P}=0.05)$ & 0.23 & NS & NS & NS & 0.49 \\
\hline \multicolumn{6}{|c|}{ Fertility levels ( $\mathrm{kg} \mathrm{N}-\mathrm{P}_{2} \mathrm{O}_{5}-\mathrm{K}_{2} \mathrm{O} / \mathrm{ha}$ ) } \\
\hline $80-40-20$ & 3.29 & 3.94 & 6.03 & 5.66 & 4.42 \\
\hline $120-60-40$ & 3.34 & 4.10 & 6.24 & 5.65 & 4.95 \\
\hline $\mathrm{CD}(\mathrm{P}=0.05)$ & NS & NS & NS & NS & 0.49 \\
\hline \multicolumn{6}{|l|}{ Cultivars } \\
\hline K 9107 & 3.34 & 4.09 & 6.61 & 6.04 & 4.99 \\
\hline Birsa Gahu-3 & 3.30 & 3.81 & 5.74 & 5.59 & 4.34 \\
\hline HUW 468 & 3.31 & 4.03 & 6.06 & 5.26 & 4.75 \\
\hline HUW 234 & 3.32 & 4.07 & 6.21 & 5.45 & 4.89 \\
\hline К 0307 & 3.31 & 4.08 & 6.05 & 5.94 & 4.45 \\
\hline $\mathrm{CD}(\mathrm{P}=0.05)$ & NS & NS & NS & NS & NS \\
\hline
\end{tabular}

drying of leaves. The leaf area index was higher in system of wheat intensification as compared to conventional method of cultivation except at 20 DAS during where due to higher plant population conventional method recorded significantly higher leaf area index than system of wheat intensification (Table 1). The leaf area index showed increasing trend at $120 \mathrm{~kg} \mathrm{~N}$ ha ${ }^{-1}, 60 \mathrm{~kg} \mathrm{P}_{2} \mathrm{O}_{5} \mathrm{ha}^{-1}$ and $40 \mathrm{~kg} \mathrm{~K}_{2} \mathrm{O} \mathrm{ha}^{-1}$ as compared to lower rate of application. As such, higher fertility level increased the supplying capacity of the soil which in turn resulted in a better leaf growth rate eventually leading to higher leaf area index. Among the cultivars, $\mathrm{K} 9107$ produced the highest leaf area index followed by HUW 234, K 0307, HUW 468 and Birsa Gehu 3. The higher LAI might be due to higher number of tillers putting forth more leaves resulting in higher leaf area index. (Tripathi et. al. 2000).

Dry matter accumulation $\mathbf{m}^{-2}$ : The dry matter accu- 
mulation $\mathrm{m}^{-2}$ increased as the growth progressed and the maximum value was observed at harvest. The dry matter production is the sum total effect of overall growth. System of wheat intensification had significant influence on dry matter accumulation at all the stages (Table 1) except at 20 DAS, where conventional method due to higher number of plant stand had higher dry matter production. System of wheat intensification had higher tillers $\mathrm{m}^{-2}$ and leaf area index indicating higher photosynthetic efficiency which in turn resulted in higher dry matter accumulation $\mathrm{m}^{-2}$. Higher fertility level of $120 \mathrm{~kg} \mathrm{~N} \mathrm{ha}^{-1}, 60 \mathrm{~kg} \mathrm{P}_{2} \mathrm{O}_{5} \mathrm{ha}^{-1}$ and $40 \mathrm{~kg} \mathrm{~K}_{2} \mathrm{O} \mathrm{ha}^{-1}$ had a significant influence on dry matter accumulation at all the growth stages of wheat. Among the cultivars, $\mathrm{K}$ 9107 and HUW 234 due to higher tiller number and leaf area index, led to higher dry matter accumulation than Birsa Gehu 3, HUW 468 and K 0307 throughout the growth period. Bhardwaj et al. (2010) also reported that enhancement in growth parameters i.e. plant height, total tillers and leaf area index were responsible for higher dry matter accumulation among the wheat cultivations.

Crop growth parameters: Pronounced improvement in crop growth rate (CGR) and net assimilation rate (NAR) were observed between 60-80 DAS and thereafter both declined till harvest. Relative growth rate (RGR) showed the declining trend from the beginning till maturity of the crop (Table 2). System of wheat intensification had positive influence on the crop growth parameters. This might be due to better vegetative growth under system of wheat intensification at the growth stages thus improving the crop growth rate, relative growth rate and net assimilation rate. Higher fertility rate of $120 \mathrm{~kg} \mathrm{~N} \mathrm{ha}^{-1}, 60 \mathrm{~kg} \mathrm{P}_{2} \mathrm{O}_{5} \mathrm{ha}^{-1}$ and 40 $\mathrm{kg} \mathrm{K}_{2} \mathrm{O} \mathrm{ha}^{-1}$ had significantly higher crop growth rate, relative growth rate and net assimilation rate due to better crop growth condition at higher fertility level. Among the cultivars, K 9107 recorded highest crop growth rate, relative growth rate and net assimilation rate as a result of better vegetative growth at all the stages.

Yield attributes: Significant improvement in yield attributes viz. number of spikes $\mathrm{m}^{-2}$, spike length, filled grains per spike, spike weight and test weight was recorded under system of wheat intensification (Table 3). This may be attributed to adequate availability and supply of resources under system of wheat intensification and their translocation along with other nutrients to the sink. The changes in the management could form more photosynthetic organ, strengthen photosynthetic ability, produce higher dry matter and provide sufficient nutrient to sink continually making the seed more plump, increased 1000-grain weight, seed setting percentage and filled grains per panicle (Lu et. al., 2005) under system of wheat intensification. Chapagain and Yamaji (2010) also reported that a wider spacing produced significantly longer panicles with higher number of filled spikelets as compared to lower spacing. Beneficial effect of fertility level on the yield 
attributes i.e. spikes $\mathrm{m}^{-2}$, spike length, filled grains per spike, spike weight and thousand grain weight was accompanied with higher fertility level i.e., $120 \mathrm{~kg} \mathrm{~N}$ $\mathrm{ha}^{-1}, 60 \mathrm{~kg} \mathrm{P}_{2} \mathrm{O}_{5} \mathrm{ha}^{-1}$ and $40 \mathrm{~kg} \mathrm{~K}_{2} \mathrm{O} \mathrm{ha}{ }^{-1}$. The increase in yield attributes might be ascribed to improved supply of nutrients at higher level, resulting into increase photosynthetic attributes and translocation of photosynthates, which promoted the growth, better partitioning of photosynthates in yield attributes and eventually produced more yield (Sen et. al., 2003). Among cultivars, K 9107 was found significantly superior to other cultivars but remained at par with HUW-234 in respect of number of spikes $\mathrm{m}^{-2}$, grains per spike and 1000grain weight. This might be due to better vegetative growth which favoured effective translocation of photosynathate resulting in higher yield attributes.

Grain and straw yield: System of rice intensification recorded pronounced effect on grain and straw yield (Table 3). Hills with wider spacing had larger root dry weights, produced greater system exudates and transport these towards shoot at faster rates, which helped maintaining higher chlorophyll levels, enhanced fluorescence and photosynthetic rates of leaves and thereby increased the yield of individual hill than closely spaced plants. Better vegetative growth which contributed towards higher dry matter accumulation resulting in significantly higher straw yield under system of wheat intensification. Significant effect of fertility levels at $120 \mathrm{~kg} \mathrm{~N} \mathrm{ha}^{-1}, 60 \mathrm{~kg} \mathrm{P}_{2} \mathrm{O}_{5} \mathrm{ha}^{-1}$ and $40 \mathrm{~kg}$ $\mathrm{K}_{2} \mathrm{O}$ ha $^{-1}$ was also recorded on grain yield. The higher values of grain yield at higher fertility level may be owing to greater availability of nutrients in soil, improvement of soil environment resulting in higher root proliferation leading to better absorption of moisture and nutrients and ultimately resulting in higher grain yield (Kumari et. al., 2013). Increased fertility level delays senescence and increases the life cycle of plant resulting in higher economic yield. The straw yield significantly increased with increased fertility level of $120 \mathrm{~kg} \mathrm{~N} \mathrm{ha}^{-1}, 60 \mathrm{~kg} \mathrm{P}_{2} \mathrm{O}_{5} \mathrm{ha}^{-1}$ and $40 \mathrm{~kg} \mathrm{~K}_{2} \mathrm{O} \mathrm{ha}^{-1}$ (Table 3). Straw yield of crop is closely related to the vegetative growth and increasing the fertility level proved instrumental in improving the growth attributes and ultimately led to higher straw yield. Cultivars like K 9107 and HUW 234 had favourably influenced dry matter accumulation and its portioning towards reproductive organs which consequently produced higher grain and straw yield.

Economics: Economics is the main factor governing the feasibility of any technology. System of wheat intensification recorded significantly higher net return and benefit cost ratio over conventional system of wheat cultivation due to higher gross return and low cost of cultivation under system of wheat intensification (Table 3). The net return and $\mathrm{B}: \mathrm{C}$ ratio were found higher at the higher fertility level of $120 \mathrm{~kg} \mathrm{~N} \mathrm{ha}^{-1}, 60$ $\mathrm{kg} \mathrm{P}_{2} \mathrm{O}_{5} \mathrm{ha}^{-1}$ and $40 \mathrm{~kg} \mathrm{~K}_{2} \mathrm{O} \quad \mathrm{ha}^{-1}$ due to higher yield.
Similarly in the case of cultivars, higher yield of $\mathrm{K}$ 9107 led to higher net return and benefit cost ratio followed by HUW 234, K 0307, HUW 468 and Birsa Gehu 3 in decreasing order.

Nutrient uptake: System of wheat intensification recorded higher uptake of nitrogen, phosphorus and potassium as compared to conventional method of cultivation which could be ascribed to better vegetative and reproductive growth under SWI method of cultivation. Total nitrogen, phosphorus and potassium uptake were higher when the crop was raised $120 \mathrm{~kg} \mathrm{~N} \mathrm{ha}^{-1}, 60 \mathrm{~kg}$ $\mathrm{P}_{2} \mathrm{O}_{5} \mathrm{ha}^{-1}$ and $40 \mathrm{~kg} \mathrm{~K}_{2} \mathrm{O}$ ha $^{-1}$ (Table 3) compared to that raised with $80 \mathrm{~kg} \mathrm{~N} \mathrm{ha}^{-1}, 40 \mathrm{~kg} \mathrm{P}_{2} \mathrm{O}_{5} \mathrm{ha}^{-1}$ and $20 \mathrm{~kg} \mathrm{~K}_{2} \mathrm{O}$ $\mathrm{ha}^{-1}$. Increase in uptake of N,P and $\mathrm{K}$ with higher nutrient doses was owing to increased availability of nutrients facilitating better root growth and as such better nutrient uptake (Singh et. al., 2011). Among cultivars, K 9107 recorded the highest NPK uptake followed by K $9107>$ HUW $234>$ K $0307>$ HUW $468>$ Birsa Gehu 3. Nutrient uptake in the product of nutrient content and grain yield. The variation in nutrient content and yield of wheat cultivars were responsible for the variability in the nutrient uptake (Kumari and Singh, 2013).

\section{Conclusion}

Thus, based on one year data it can be concluded that wheat variety $\mathrm{K} 9107$ fertilized with $120 \mathrm{~kg} \mathrm{~N} \mathrm{ha}^{-1}, 60$ $\mathrm{kg} \mathrm{P}_{2} \mathrm{O}_{5} \mathrm{ha}^{-1}$ and $40 \mathrm{~kg} \mathrm{~K}_{2} \mathrm{O} \mathrm{ha}^{-1}$ under System of Wheat Intensification may prove as biologically efficient, resource conservative, highly profitable system under irrigated ecosystem of Chhotanagpur plateau region, India which has the potential to serve as a viable and better alternative to the farmer.

\section{REFERENCES}

Bhardwaj V Yadav V and Chauhan BS (2010). Effect of nitrogen application timings and varieties on growth and yield of wheat grown on raised bed. Archieves of Agronomy and Soil Science, 56 (2): 211-222.

Chapagain T and Yamaji E (2010). The effects of irrigation method, age of seedling and spacing on crop performance, productivity and water wise rice production in Japan. Paddy water environment, 8: 81-90.

Chatterjee Kaushik Singh CS Singh Arvind Kumar and Singh Ashok Kumar (2012). Performance of Wheat cultivars at varying fertility levels under system of wheat intensification and conventional method of wheat production system. $3^{\text {rd }}$ National Symposium on Agriculture Production and Protection in Context of Climate Change at Birsa Agricultural University, Ranchi, Jharkhand, 03-05 November, 2012 pp70.

Gomez, K.A. and Gomez, A.A. (1984). Statistical Procedures for Agricultural Research $2^{\text {nd }}$ Edn. John Willey and Sons, New York.

Jackson, M.L. (1973). Soil Chemical Analysis, Prentice Hall of India Ltd. New Delhi, pp. 183-04.

Kumar A and Singh VP (2003). Effect of graded levels of NPK on yield and NPK uptake in wheat varieties. $R A U$ Journal of Research, 13 (1\&2): 87-90. 
Kumari Niru Singh CS Prasad J Singh MK and Kumar R (2013). Influence of organic nutrient sources on productivity of rice (Oryza sativa) - based cropping system in Jharkhand. Indian Journal of Agronomy ,58(3): 277 281.

Lu Y Li JY wang J.C Tang YQ and Yu GP (2005). Effect of SRI on dry matter production and grain yield of Yuyou 11. Southwest China Journal of Agricultural Sciences, 18 (6): 719-723.

Mehla DS and Gupta AP (1998). Optimum fertilizer nitrogen dose for wheat (Triticum aestivum) varieties under rice (Oryza sativa)-wheat cropping sequence. Indian Journal of Agricultural Sciences, 68 (6): 287-291.

Nicholas, D.J.D. and Nasan, A. 1957. Determination of nitrate and nitrite. Academic Press (Elsevier BV), New York, Methods in Enzymology, 3: 981-84.

Sen A Pandey MD Sharma SN Singh RK Kumar A Shukla P and Srivastava VK (2003). Surface seeding of wheat as affected by seed rate and nitrogen level. Indian journal of Agricultural sciences 73(9): 509-511.

Singh CS Singh Kumar A and Singh Kumar A (2011). Growth and yield response of rice to varying levels of fertility, sulphur and zinc under transplanted condition. Environment and ecology 29(3): 978-984.

Thakur AK Rath S Roychowdhur S Uphoff N (2010). Comparative performance of rice with system of rice intensification (SRI) and conventional management using different plant spacings. Journal of Agronomy and crop science 196 (2): 146-159.

Tripathi ML Kurmvanshi SM and Kushwaha (2000). Studies on seed rate and row spacing on rainfed wheat (Triticum aestivum) in Vindhya Plateau of Madya Pradesh. Agricultural Science Digest 20(3): 197-198. 